\title{
FEDERAL GIVIL PROCEDURE: SUBSTITUTION UNDER AMENDED RULE 25(a) (1)
}

IN SEPTEMBER 1962, the Judicial Conference of the United States
presented to the Supreme Court a number of proposed amendments to the Rules of Civil Procedure ${ }^{1}$ which were adopted by the Court in January 1963.2 Among the rules which were substantially amended was 25 (a) (1), ${ }^{3}$ possibly the most censured of all the Federal Rules. ${ }^{4}$ In order to evaluate critically the amended rule, it is necessary to examine the peculiar problems which arose under the old rule and the historical context which spawned them.

\section{The Oruginal Rule: History and Criticism}

Rule 25 (a) (1) provides for substitution of a legal representative where one of the parties to an action dies, becomes incompetent or transfers his interest. It provides a time limit for revivor but in no way affects the question of whether a cause of action survives. ${ }^{5}$

\footnotetext{
1 The proposed amendments were presented to the Court pursuant to authority conferred on the Conference by statute. "The Conference shall also carry on a continuous study of the operation and effect of the generai rules of practice and procedure. . . Such changes in and additions to those rules as the Conference may deem desirable to promote simplicity in procedure, fairness in administration, the just determination of litigation and the elimination of unjustifiable expense and delay shall be recommended by the Conference from time to time to the Supreme Court for its consideration and adoption, modification or rejection, in accordance with law." 28 U.S.C. $\$ 331$ (1958).

The Court has the power to adopt rules for the district courts without further congressional approval. However, the rules do not take effect unless they are reported to Congress and until the expiration of ninety days thereafter. 28 U.S.C. $\$ 2072$ (1958).

3 "If a party dies and the claim is not thereby extinguished, the court [within 2 years after the death] may order substitution of the proper parties. [If substitution is not so made, the action shall be dismissed as to the deceased party.] The motion for substitution may be made by any party or by the successors or representatives of the deceased party [or by any party] and, together with the notice of hearing, shall be served on the parties as provided in Rule 5 and upon persons not parties in the manner provided in Rule 4 for the service of a summons, and may be served in any judicial district. Unless the motion for substitution is made not later than 90 days after the death is suggested upon the record by service of a statement of the fact of the death as provided herein for the service of the motion, the action shall be dismissed as to the deceased party." FED. R. Crv. P. 25 (a)(1). (New matter is shown in italics and deleted matter in brackets.)

4 See 2 Barron \& Holtzoff, Federal Practice and Procedure \$621, at 420 (Wrighit ed. 1961) [hereinafter cited as Barron \& Holtzoff]; 4 Moore, Federal Practice q 25.01, at 510 (2d ed. 1950) [hereinafter cited as MOORE].

- Rule 25 (a) (1) is procedural in that it merely provides the manner and means by which substitution may be accomplished if the cause of action survives under the
} 
The rule became effective in 1938 and was not amended during the subsequent twenty-five years until the recent Supreme Court action. The Advisory Committee ${ }^{6}$ notes indicate that section 778 of the Judicial Code ${ }^{7}$ and Equity Rule $45^{8}$ were common bases of this federal revivor rule; ${ }^{\theta}$ however, Professor Moore maintains that the real basis was section 778 alone.10 Whatever its original basis, rule 25 now stands without statutory support. ${ }^{11}$ This situation has resulted in the most serious as well as the most perplexing of the three major substitution problems discussed in this paper.

Validity of $25(a)(1)$

The validity of 25 (a) (1) has been the subject of legal controversy throughout the rule's history. Though the question has been argued

appropriate state or federal law. Commercial Solvents Corp. v. Jasspon, 92 F. Supp. 20 (S.D.N.Y. 1950). It applies, of course, only to civil actions in the district courts. It allows the motion for substitution and notice of hearing to be served in any judicial district, hence allowing the substitution of a foreign administrator even though the state court would not permit such procedure. Iovino v. Waterson, 274 F.2d 41 (2d Cir. 1959), cert. denied, 362 U.S. 949 (1960).

'The Advisory Committee on Civil Rules was established in 1960, replacing the Advisory Committee which was discharged in 1956. Its function is to conduct basic studies and prepare reports and recommendations. Reports are compiled for the Standing Committee on Rules of Practice and Procedure which in turn reports to the Judicial Conference. 1 BARRon \& Holtzoff (Supp. 1962, at 9).

7 "When either of the parties . . . dies before final judgment, the exccutor or administrator of such deceased party may, in case the cause of action survives by law, prosecute or defend any such suit to final judgment. ... Courts shall have jurisdiction within two years from the date of the death of the party to the suit to issue its scire facias to executors and administrators appointed in any State or Territory of the United States which may be served in any judicial district by the marshal thereof: Provided, however, that no executor or administrator shall be made a party unless such service is made before final settlement and distribution of the estate of said deceased party to the suit." Act of Dec. 22, 1921, ch. 18, 42 Stat. 352. 993.

Section 778 was repealed in 1948. Act of June 25, 1948, ch. 646, §39, 62 Stat. 869,

8 "In the event of the death of either party the court may, in a proper case, upon motion, order the suit to be revived by the substitution of the proper parties. If the successors or representative of the deceased party fail to make such application within a reasonable time, then any other party may, on motion, apply for such relief, and the court, upon any such motion may make the necessary orders for notice to the partics to be substituted and for the filing of such pleadings or amendments as may be ncces. sary." Equity R. 45, 226 U.S. 661 (1912).

8 "The first paragraph of this rule is based upon Equity Rule 45 (Death of PartyRevivor) and U.S.C., Title 28, $\$ 778$ [1946 Ed.] (Death of parties; substitutions of executor or administrator). The scire facias procedure provided for in the statute cited is superseded and the writ is abolished by Rule 81 (b)." Advisory Committce Notes to rule 25 (note to subdivision (a)(1) (1937)), as reprinted in $3 A$ BARRON \& HoLTZOFF 453.

104 MOORE If 25.01, at 505. But see Note, 45 VA. L. REv. 75, 77 n.7 (1959) where it is stated that the provision for substitution by motion apparently is derived from the equity rule.

${ }^{11}$ See note 7 supra. 
in treatises, in law reviews and in the courts, it is still undecided. ${ }^{12}$ The main point of dissension is whether the two-year time limit is substantive in nature or merely procedural, and, if substantive, whether it has the force of a statute due to its peculiar history. The Enabling Act of 1934 warns that the rules "shall neither abridge, enlarge nor modify the substantive rights of any litigant,"13 and, of course, the Erie doctrine raises the substantive versus procedural question in diversity cases. ${ }^{14}$ Thus, if the substantive rights of any litigant are abridged by the operation of 25 (a) (1), one may conclude that the rule is invalid. ${ }^{15}$

The Supreme Court thoroughly discussed rule 25 (a) (1), in Anderson $v$. Yungkau $u^{16}$ and found that the rule operated both as a statute of limitations and as a mandate to the court to dismiss when the twoyear period had run, regardless of extenuating circumstances. Since Anderson was decided prior to the repeal of section 778, however, the rule had the force of the statute to sustain it, thereby precluding any question as to its validity. The problem has recurred frequently since 1948, however, with the courts and commentators splitting in their decisions and interpretations. ${ }^{17}$ It would be extremely difficult

${ }^{12}$ Compare Perry v. Allen, 239 F.2d 107 (5th Cir. 1956) and 4 MOORE If 25.01, at 510, with lovino v. Waterson, 274 F.2d 41 (2d Cir. 1959), cert. denied, 362 U.S. 949 (1960) and 45 CALIF. L. REv. 785 (1957).

1328 U.S.C. $\$ 2072$ (1958).

14 Erie R.R. v. Tompkins, 304 U.S. 64 (1938). The Court held that neither Congress nor the federal courts have the power under the Constitution to declare substantive rules of common law applicable in a state. Except in matters governed by the federal constitution or by acts of Congress, moreover, the law to be applied in any case is the law of the state.

15 "If this statute of limitations on revivor is, indeed, substantive, then it is invalid in diversity cases because of conflict with the Erie doctrine, and it is invalid in federal matters because beyond the scope of the rule-making power." Wright, Amendments to the Federal Rules: The Function of a Continuing Rules Committee, 7 VAND. L. REV. 521,528 n.19 (1954).

10329 U.S. 482 (1947).

${ }^{17}$ One group of authorities holds that the rule as it has stood since 1948 is invalid. Perry v. Allen, 239 F.2d 107 (5th Cir. 1956); Fenebry v. Sims, 22 F.R.D. 10 (E.D.N.Y. 1958); 4 MOORE If 25.01, at 510; Holtzoff, Should the Federal Rules of Civil Procedure be Amended?, 36 U. DEr. L.J. 47, 54 (1958); Wright, supra note 15. The argument begins with the proposition that 25 (a) (I), if rigidly applied, acts as a statute of limitations. A statute of limitations, moreover, is substantive in nature. Guaranty Trust Co. v. York, 326 U.S. 99 (1945). Therefore, the argument continues, since the rule no longer has statutory support, it is invalid insofar as it abridges substantive rights.

On the other hand, another group of authorities contends that the rule is valid. Iovino v. Waterson, 274 F.2d 41 (2d Cir. 1959), cert. denied, 362 U.S. 949 (1960); Pritchard v. Downie, 201 F. Supp. 893 (E.D. Ark. 1962); Starnes v. Pennsylvania R.R., 26 F.R.D. 625 (E.D.N.Y.), aff'd, 295 F.2d 704 (2d Cir.), cert. denied, 369 U.S. 813 (1961); Zdanok v. Glidden Co., 28 F.R.D. 346 (S.D.N.Y. 1961); Foltz v. Moore-McCormack Lines, Inc., 19 F.R.D. 301 (S.D.N.Y. 1956); Gertler v. United States, 18 F.R.D. 307 
to decide where the weight of authority lies. Whichever view one takes, the problem persists; whether the new amendment provides a solution remains to be seen. ${ }^{18}$

\section{Dismissal With Prejudice}

Another question which has generated confusion among the courts is whether dismissal under 25 (a) (1) is with or without prejudice. Although the incidents of a dismissal without prejudice can be onerous, ${ }^{19}$ they are certainly less harsh than having no remedy at all. Nevertheless, it would seem that the better view is that a dismissal is with prejudice unless the trial judge specifies otherwise. ${ }^{20}$ It has been suggested by one writer that the judge should exercise his discretion and dismiss without prejudice when the failure to revive in the allotted time is due to excusable neglect. ${ }^{21}$ This procedure appeals to one's sense of justice, but it is inconsistent with the language used by the Supreme Court in Anderson v. Yungkau. ${ }^{22}$ The divergent interpretations of this important question highlight the existing confusion and focus attention on the desirability of delimiting the judge's discretion in dismissing with or without prejudice.

(S.D.N.Y. 1955); Note, 45 VA. L. REV. 75 (1959); 45 CALIF. L. REv. 785 (1957); 70 HARV. L. Rev. 1471 (1957); 105 U. PA. L. REv. 1098 (1957); 43 VA. L. Rev. 431 (1957). The rationales advanced by this group are varied and difficult to summarize briefly. However, most of the authorities cited base their conclusions either on the belief that a statute of limitations is not substantive when used in the context of revivor, or on the conclusion that although the rule affects the substantive rights of the parties, the legislative history of the repeal of $\$ 778$ gave to the rule the force of a statute. For a thorough and well-reasoned discussion of the entire question, see Note, 45 VA. L. REv. 75 (1959) which concludes that rule 25 (a)(1) is procedural as far as non. diversity cases are concerned and therefore valid, whereas different policy considera* tions in diversity cases may require the application of the state law in apposition to the federal rule. Pritchard v. Downie, supra, reaches the same conclusion.

${ }^{18}$ See discussion p. 740 infra.

${ }^{10}$ The dismissed party loses his place on the trial calendar, is forced to suffer the expense of instituting a new suit, and faces the possibility of the statute of limitations running on his cause of action.

${ }_{20} 2$ BARRON \& HoltzofF $\S 622$, at 425. In Anderson v. Yungkau, 329 U.S. 482, 486 (1947), the Court, after finding that rule 25 (a) (1) operates as a statute of limitations, pointed out that a statute of limitations normally closes the door finally, not qualifiedly or conditionally. Contra, Bush v. Remington Rand, Inc., 213 F.2d 456 (2d Cir.) (dictum), cert. denied, 348 U.S. 861 (1954); Zdanok v. Glidden Co., 28 F.R.D. 346 (S.D.N.Y. 1961); Gertler v. United States, 18 F.R.D. 307 (S.D.N.Y. 1955).

${ }_{21}$ Note, 45 VA. L. Rev. 75, 89.90 (1959). The writer argues that a dismissal on the merits, where there is a reasonable excuse for failure to revive in the time allotted, should constitute reversible error since the use of the power given under rule 41 (b) must not amount to an abuse of discretion.

${ }^{29}$ See note 20 supra. 


\section{Unfairness}

The strongest criticism by far of rule 25 (a) (1) has not been concerned with the technical uncertainties discussed above but has been directed toward the hardships and inequities worked by the operation of the rule.23 The unyielding time limit, rigorously enforced, has been termed a trap for the unwary which has "led to harsh results contrary to the beneficial purposes stated in Rule 1."24 The Anderson decision is particularly illustrative of such a result. The petitioner in that case was suing to recover stock assessments from shareholders of the Banco Kentucky Company. ${ }^{25}$ A prior case had wended its way through the courts in order to establish the liability of the shareholders for the assessment. During this time, some of the approximately 5000 shareholders had died, and the petitioner was seeking to revive the action against their executors. The Court found that it was through no lack of diligence that petitioner failed to discover all the deaths in the two-year period following the institution of the original actions. Nevertheless, the Court held that an extension of time was forbidden by rule 25 (a) (1). ${ }^{26}$

However, at least two courts have managed to circumvent the strict time limit in particularly appealing cases and at the same time uphold the validity of the rule. In Bush $v$. Remington Rand, Inc. ${ }^{27}$ and Iovino $v$. Waterson ${ }^{28}$ the courts resorted to the device of estoppel to deny the motion to dismiss. In the former case, the defendant knew of the death of one of the plaintiffs, yet made no objection while the other plaintiffs expended money and effort bringing the case to judgment. The defendant was held to have waived the statute of limitations prescribed by the rule. In Iovino plaintiff remained unapprised of the defendant's death throughout the pretrial interval. The defendant's lawyer participated in pre-trial conferences without mentioning the fact of the death until after the

\footnotetext{
${ }^{23}$ See authorities cited note 4 supra.

a 2 BARRoN \& HoltzoFf $\$ 621$, at 420 .

${ }^{25}$ The Anderson case was a cousolidation of several suits by the petitioner against individual defendants. 329 U.S. at 483.

${ }^{20}$ At the time Anderson was decided, rule $6(\mathrm{~b})$, which allows an extension of the time limits prescribed by the Federal Rules, did not include rule 25 as an exception. Subsequent to this decision, however, 6 (b) was amended to include rule 25 as one of the rules in which the time limit could not be extended, and it so remained until the adoptiou of the recent amendments.

27213 F.2d 456 (2d Cir.), cert. denied, 348 U.S. 861 (1954).

${ }^{28} 274$ F.2d 41 (2d Cir. 1959), cert. denied, 362 U.S. 949 (1960).
} 
two-year period had run. ${ }^{29}$ Again the court held that the moving party was estopped to object. Thus, these two decisions offer a means of mitigating the harshness of 25 (a) (1) where elements of estoppel exist. The majority of cases, however, have no such elements but arise solely from excusable neglect. ${ }^{30}$ The resulting hardship and inequity was the only reason stated by the Advisory Committee in favor of the recently adopted amendment and was the motivating force in all three attempts to amend. ${ }^{31}$

\section{Earlier Proposed Amendments}

The proposed, but unadopted, amendments to rule 25 (a) (1) have attempted to rectify the problem of unfairness in a variety of ways. The Advisory Committee's proposal in 1946 would have made substitution of the proper parties mandatory upon timely application, and discretionary upon a showing of a reasonable excuse for failure to apply within the proper period. ${ }^{32}$ It is submitted that this approach is an unsatisfactory method of dealing with the revivor question. Possibly the most important policy consideration in setting a time limit at all is the expeditious settling of the deceased party's estate. This policy can be seriously impaired where substitution is mandatory for two years. The Court pointed out in Anderson that "the settlement and distribution of the estate might be so far advanced as to warrant a denial of the motion for substitution within the two-year period." 33 It would seem wise, therefore, to give the court discretion to deny substitution after a reasonable period has .elapsed.34 Why the Supreme Court failed to adopt the proposed amendment is a matter of conjecture. The more probable reason is that the Anderson case was pending before it at the time. ${ }^{35}$ However, it is certainly possible that the Court looked at the merits of the proposal and decided against it on grounds similar to the ones discussed above.

\footnotetext{
${ }^{29}$ It appears that the lawyer was retained by the original defendant's insurance company after the defendant's death. See 73 Harv. L. Rev. 1618 (1960).

${ }^{30}$ See, e.g., Zdanok v. Glidden Co., 28 F.R.D. 346 (S.D.N.Y. 1961) which indicated approval of the estoppel cases but which held that the facts in that case amounted only to excusable neglect and did not raise an estoppel.

${ }_{31}$ "The hardships and inequities of this unyielding requirement plainly appear from the cases." Advisory Committee Note to amended rule 25 (1962).

${ }^{32}$ See the Advisory Committee's proposed but unadopted 1946 amendment to rulc 25, as reprinted in 4 MOORE \I 25.01, at 503-04.

Rs 329 U.S. at 485.

"See discussion p. 740 infra.

as For a discussion of the possible reasons, see 4 MOORE \ 25.01, at 504 .
} 
In 1954 another attempt to amend rule 25 (a) (1) was initiated. The Advisory Committee in that instance proposed to eliminate the time limit altogether and to substitute the concept of reasonableness. ${ }^{36}$ Although this approach would probably afford a fairer result in many fact situations, it would create new evils in that the parties could never be certain how long they could safely wait to move for substitution. ${ }^{37}$ In addition, a court might be placed in an awkward situation where, upon the imminent settlement of the defendant's estate, the plaintiff has an appealing excuse for his delay in moving to substitute. Moreover, if the plaintiff should die and nothing were said to the defendant about substituting the administrator, the defendant is caught in an equally awkward position: He does not want a suit hanging over his head without knowing when or if it is going to be revived; at the same time he might be afraid to move for dismissal and remind the administrator of the pending action.

\section{The New Amendment}

Rule 25 (a) (1) now provides that unless a motion for substitution is made within ninety days after the suggestion of death upon the record ${ }^{38}$ the action shall be dismissed as to the deceased party. Taken in conjunction with the new amendment to rule $6(\mathrm{~b})$, which permits the trial judge to extend the time limit where there is excusable neglect, ${ }^{39}$ rule 25 (a) (1) has been substantially revised. As now provided, the time limit starts running at the time the death is suggested upon the record, rather than at the time of the death. In place of the old two-year period, however, a very much shorter ninetyday period has been substituted. Moreover, a motion to substitute may be made without awaiting the suggestion of death. On the

so "If substitution is not made within a reasonable time, the action may be dismissed as to the deceased party." Advisory Committee's proposed but unadopted amendment to rule 25 (1955), as reprinted in 3A BARRoN \& HolTzOFF 552.

Though the Committee was primarily interested in fairness, one may reasonably infer that the complete elimination of a time limit resulted from doubts as to the validity of such a restriction.

${ }^{37}$ Although granting the substitution motion was not technically mandatory even under the old rule, nevertheless, if one moved for substitution within two years, he could be virtually certain of success. The writer's search has uncovered no case where substitution was not allowed within the two-year period.

${ }^{38} \mathrm{~A}$ new form has been adopted for the purpose of suggesting the death upon the record: "A.B. (describe as a party, or as executor, administrator, or other representative or successor of C.D., the deceased party) suggests upon the record, pursuant to Rule 25 (a) (1), the death of C.D. (describe as party) during the pendency of this action." FED. R. CIv. P. Form 30.

${ }^{30}$ Rule 6 (b) was amended simply by eliminating rule 25 from the exceptions to the rule. See discussion note 26 supra. 
other hand, if one wishes to limit the time in which another may make the motion, he can do so by suggesting the death upon the record. Unlike the 1946 proposal, the permissive language of the first sentence in the old rule is retained; therefore, a motion to substitute may be denied, even if it is made within ninety days of the suggestion of death, if such suggestion is unreasonably delayed and the court thereby deems it unfair to allow substitution.

\section{Validity of New Rule}

Since rule $6(\mathrm{~b})$ has been amended to allow the trial judge to extend the time limit for excusable neglect, 25 (a) (1) as amended will probably be considered valid by most of those who previously questioned its validity. In Perry $v$. Allen, the court talked in terms of placing an "absolute time limit upon the assertion of a right"40 and placing a "categorical and inflexible time limit upon his right to substitute." 41 If the unyielding quality of the time limit was the reason the court considered the rule invalid, as its use of words implies, that infirmity is cured. In Henebry v. Sims, moreover, a New York district court said: "Rule 25 (a) is invalid insofar as it attempts to abridge the plaintiff's substantive right to bring her action to trial by placing a fixed time upon her right to apply for a substitution for the deceased defendant."42 (Emphasis added.) It the key word is "fixed," this court also should be satisfied. However, in the Perry decision, extensive reference is made to Professor Moore's analysis, ${ }^{43}$ and it is questionable whether the new rule will meet his test of validity. He did say that the proposed 1946 amendment, which had the discretionary feature of the new rule, "would have given flexibility and would probably have adequately cared for the situation where the party seeking substitution had been diligent."44 Moore's limited approval extends only to the fairness of the rule, however, and not to its validity. Moore specifically prescribes the principles which he maintains should govern:

(1) If the action involves a federal matter and the suit is equitable, substitution could be made within a reasonable time. ... [I]nexcusable delay in the nature of laches would be the only time bar. If the suit is legal, the state time period for making substitution would govern.

\footnotetext{
${ }^{\circ}$ Perry v. Allen, 239 F.2d 107, 111 (5th Cir. 1956).

$11 d$. at 112.

45 Henebry v. Sims, 22 F.R.D. 10, 12 (E.D.N.Y. 1958).

4239 F.2d at 111 . Henebry v. Sims, supra note 42, does not mention Professor Moore but relies heavily on Perry $v$. Allen and adopts the same argument.

14 MOORE If 25.01, at 510 .
} 
(2) If the action involves a nonfederal matter the time within which substitution must be made would be governed by state law, whether the suit be equitable or legal, under the principles of Erie-Tompkins. ${ }^{45}$

Thus, Moore seems to feel that any time limit prescribed by the Federal Rules is invalid, absent statutory support, whether it is flexible or not. It therefore appears that no rule will satisfy everyone as to its validity, except one which merely incorporates the principles set forth by Moore above. Nevertheless, many courts upheld 25 (a) (1) in its prior form and one can assume that the courts which challenged it will be less inclined to do so now that the sting has been removed. It can reasonably be anticipated, therefore, that the new rule will be upheld.

\section{Fairness of the New Rule}

There is no doubt that the amended rule 25 (a) (1), in conjunction with the amendment of 6 (b), will operate more fairly than the old rule. In a case like Anderson, the court will have discretion to extend the time limit, thereby allowing the diligent attorney more time to learn the facts and act upon them. Furthermore, the new rule will achieve a fairer result in the case of a plaintiff's death. The defendant may suggest the death upon the record and thus require the representative of the deceased plaintiff to move for substitution within ninety days or be dismissed. Moreover, if the defendant is the deceased party, his representative may follow the same procedure, thus forcing the plaintiff to come to a decision on whether to press his law suit or not. The overall effect, therefore, will be a speedier determination of the status of the suit. Although the plaintiff will not have as much time to act, the amendment to rule $6(\mathrm{~b})$ will afford him relief if the facts so justify, even if he waits until after the time limit has run to move for an extension.

\section{Proposed Better Rule}

Amended rule 25 (a) (1) seemingly effects a substantial improvement in terms of solving the problems which arose under the old rule and meeting the needs of the parties and their counsel. It eliminates the worst fault of the 1946 proposal-the mandatory substitution within two years after the death. Moreover, it does not eliminate a time limit altogether, as the 1954 proposal would

${ }^{6}$ Id. I 25.06 , at 523 . 
have done. It is submitted, however, that the rule could be improved in at least two respects.

As it stands now, the plaintiff, in the event of the defendant's death, cannot be absolutely certain that his motion to substitute will be granted at any time, however soon it may follow the death. Therefore, it is suggested that during some period, not over 180 days, the plaintiff have an absolute right to substitute, limited only by the ninety-day period if the fact of death is suggested on the record. ${ }^{46}$ It has also been seen that, if the defendant or his representative prefers not to suggest the fact of death for some tactical reason, he is at a loss as to when he safely can move to dismiss. Therefore, it may be fairer to the defending party to set a time limit of one year from the date of death after which he can move for a dismissal and be certain, absent elements of estoppel or excusable neglect, that it will be granted. However, dismissal in this case should not be with prejudice, so as not to fall into the pattern of the old rule. The burdens connected with a dismissal without prejudice would be sufficient to encourage the plaintiff's representative to make his decision within the year. Since the court now has discretion to extend the time limits prescribed by the rule, all other dismissals should be with prejudice. This point should be brought out in the rule itself in order to eliminate any possible confusion.

\footnotetext{
${ }^{26}$ The six-month period is suggested as a reasonable compromise between the two conflicting policies of allowing the plaintiff sufficient time to revive the action and insuring that the settlement of the defendant's estate will not be unconscionably delayed.
} 